\title{
Critical Leadership Style Actions for Improving Construction Personnel Performance in South Africa
}

\author{
Chijioke Emere $^{1 *}$, Clinton Aigbavboa', Wellington Thwala' \\ ${ }^{1}$ Department of Construction Management and Quantity Surveying, Faculty of Engineering and the Built Environment, \\ University of Johannesburg, P. O. B. 524, 2006 Johannesburg, South Africa \\ * Corresponding author, e-mail: cemere@uj.ac.za
}

Received: 13 November 2020, Accepted: 13 September 2021, Published online: 05 November 2021

\begin{abstract}
The successful performance of any enterprise is connected to adequate leadership. For construction, leadership is much needed to effectively manage the project team towards achieving the set goals. Hence, certain leadership actions are conducive for boosting the performance of the relevant stakeholders and personnel in any project undertaking of which will, in turn, contribute to timeous project delivery. This paper aims to investigate the critical leadership style actions essential for the enhancement of personnel performance in the South African construction industry. The primary and secondary research data were collected through a structured questionnaire. The survey was conducted in the Gauteng Province of South Africa. Respondents were construction professionals selected using heterogeneity and convenience sampling techniques. Data were analyzed using Statistical Package for the Social Sciences (SPSS) version 25.0 software. Mean values and standard deviation were computed, and the ranks of the outputs were established. Findings from the study revealed that by giving proper instructions and clarifying procedures jobs are completed on time. Additionally, the involvement of team members in decision-making helps build trust and facilitates a good relationship in the work environment. Furthermore, the study revealed that recognizing personnel contributions by showing appreciation for individual excellence is vital for optimum performance. Other notable findings include the provision of necessary resources while letting them do the work, and the ability to make quick decisions. The study findings add to literature particularly on certain style actions to be adopted which will aid effective leadership in construction project delivery in South Africa.
\end{abstract}

Keywords

construction industry, leadership, leadership theory, leadership styles, organizational success

\section{Introduction}

Leadership has been observed as fundamental to the success of any group or organization (Okoroji et al., 2014). Therefore, leadership style in the construction industry cannot be overemphasized in influencing personnel towards the attainment of project objectives. In the construction industry, people work per targeted times and sometimes work under pressure, in such instances, you cannot negate adequate leadership for maximum performance (Emere et al., 2018; Liphadzi, 2015). Besides, the fact that the South African construction industry has a bearing on the economy of the country makes the subject leadership more essential. In South Africa, the construction industry contributes more than $10 \%$ to the GDP (Statistics South Africa, 2014). It also employs about $7 \%$ of the total national labor force (Statistics South Africa, 2011). Hence, its overall performance influences the economic abundance of the country. Therefore, adequate leadership is tremendously needed within its sectors for efficiency and productivity. However, little has been said in the South African construction industry concerning leadership and its vitality in improving personnel performance (Liphadzi, 2015). In addition, the industry has suffered the consequences of leadership incapability along with challenges such as slowness in adapting to change, unpreparedness to uncertain future, and inappropriate implementation of a strategic plan to mention but a few (Liphadzi, 2015). Without good leadership people do what seems good in their own eyes; moving like sheep without a shepherd (Emere et al., 2018). Unfortunately, labor performance is solely based on productivity (Havenga, 2002). The ability of the project leaders and superintendents to effectively motivate and navigate their subordinates will determine the success of the 
labor on the job (Havenga, 2002). Therefore, leadership has a say in employees' attitudes, behaviors, and performance in any organization (Adogbo et al., 2017; Emere et al., 2018). Leadership even goes a long way in maintaining staff morale and engagement (Adogbo et al., 2017). Also, it entails the support of an individual to a group of people in all the essentials necessary to the attainment of the set goals (Adogbo et al., 2017; Emere et al., 2018). Furthermore, Leadership also calls for creativity, calculated risk-taking, the ability to inspire and influence others, as well as winning with people rather than maintaining standards or just meeting targets (Jarad, 2012; Maxwell, 2007). Hence, certain style actions are required for the leader to influence his/ her subordinates towards getting the job done. Some actions may thrive well than orders depending on certain circumstances and environments. Improving personnel performance in a project environment, therefore, requires a clear understanding of what actions are critical for each style of leadership used. Consequently, this paper aims to answer that question. The study will also reveal certain style actions that may not be favorable for performance increase. The remainder of this article is organized as follows. Section 2 presents a detailed discourse on leadership, leadership style, and leadership theories. Section 3 discusses the method used in conducting the study; while Section 4 presents the findings. Finally, Sections 5 and 6 present the conclusion of the study and references respectively.

\section{Leadership and leadership style}

Leadership is more about influence (Maxwell, 2007). According to Clark and Clark (1994), leadership is a process by which a person influences other(s) to accomplish an objective and directs the organization in a way that makes it more cohesive and coherent. Munroe (2005:p.52) also defined leadership as "the capacity to influence others through inspiration motivated by a passion, generated by a vision, produced by a conviction, ignited by a purpose". In other words, a leader should have the capacity to envisage a future event; aligns people with that vision, and motivate them to actualize the desired goal irrespective of challenges (Emere et al., 2018; Kotter, 1988). Leadership style on the other hand can be defined as the prevalent and consistent behavioral pattern a leader uses to increase his or her influence on the subordinates (DuBrin, 2010). Meaning that attitudes and behaviors when consistently combined in dealing with subordinates are point notes for the discovery of one's style of leadership (Price, 2009). In addition, leadership style deals with the interaction/ relationship of a person and the individuals he or she seeks to lead (Groetsch and Davis, 2006). To empower and influence others to make decisions there should be a relationship in place (Havenga, 2002; Kouzes and Posner, 1996). Literature also extends that though the style is a vital key in influencing subordinates as a leader, there has not been concrete proof that one style is greater than the other (Giritli and Oraz, 2004). Certain behavioral styles thrive well in some cultures than in others (Liphadzi, 2015; Price, 2009). The hallmark of effective leaders is that they vary their leadership style based on their context, proper knowledge of the environment and circumstances, and the understanding of followers' attributes and behaviors (Bass and Avolio, 1994; Müller and Turner, 2007). Flexibility in the style of leadership as occasion demands when managing projects is therefore required for the project leaders if they are to achieve maximum influence on their subordinates.

\subsection{Theories of leadership}

The concept of Leadership and its theories are gradually evolving because of differences and changes in human behaviors, norms, perceptions, and understanding (Daft, 2015). According to Bolden et al. (2003) the early theories major on the characteristics and behavior of successful leaders, while the later theories focus on what leaders do (contextual nature of leadership) as well as the role of followers. Tabassi and Bakar (2010) affirmed that various Leadership theories are necessary as they assist in the understanding of the chosen leadership style adopted by the leader in any given situation. However, not much progress has been made in the adoption of leadership theories in the construction industry when compared to the general leadership literature on leadership theories (Chan and Chan, 2005). The predominant and most written leadership theories can be classified.

\subsubsection{Great man's theory}

According to Daft (2015), Great man's theory is the granddaddy of leadership concepts. It assumes that the ability to lead is inherent. In other words, great leaders are born and not made (Boerma et al., 2017; Daft, 2015). Here, the leader is said to be naturally endowed with power, influence, and heroic leadership traits (Bass, 1990; Daft, 2015). These great leaders manifest when faced with the right challenge and were being regarded as exceptional because their impacts have had a long-lasting impression on humanity (Daft, 2015). Additionally, the term "Great Man" came from the notion that only a man could have the qualities 
of a great leader (Bass, 1990). Hence, leadership in its early stage was seen as a single "Great Man" who took absolute control and influences others to follow through based on the inherent qualities and strength (Bass, 1990; Daft, 2015). This leadership concept was used in many organizations, religions, and social movements, governments, and the military (Daft, 2015).

\subsubsection{Trait theory}

This theory is like Great Man's theories in some ways, because it assumes that people inherently possess certain attributes and traits that are leadership inclined (Daft, 2015). This theory extends that a leader is either born or made with certain qualities needful for excellence in leadership (Bass, 1990). This is supported by Furnham (2005) who affirms that traits theory postulates those characteristics such as interpersonal and cognitive skills which are trends of an individual's potential for leadership roles. The trait theory focused on the analysis of mental, physical, and social characteristics to gain more insight into the common characteristics among leaders (Wren, 1995). The predominant thought was that the identification of traits calls for accurate prediction of leadership ability in an individual or potential leader in the making (Bass, 1990; Wren, 1995). However, researchers are still oblivious of which trait would always guarantee leadership success and the search for better leadership traits has continued to this day (Daft, 2015).

\subsubsection{Behavioral theory}

This theory came into existence due to the inability to find a universal set of leadership traits that compelled researchers of the early 1950 s to search for the predominant attitude of a leader than just positional/identity (Daft, 2015). They tried to determine how they delegate tasks, how they communicated with and tried to motivate subordinates, and how they carried out their tasks (Stoner and Freeman, 1989; Daft, 2015). Hence, discovering the distinction between the behavioral attitudes of effective leaders from that of ineffective ones and observing and categorizing their different patterns of behaviors (e.g. autocratic or democratic approach) as styles of leadership (Bolden et al., 2003). The behavioral theory grew as researchers became more and more convinced that effective leaders can be discerned by their actions (Stoner and Freeman, 1989) and not just a disembodied entity endowed with unique characteristics.

\subsubsection{Contingency/situational theory}

This theory tried to explain that no leadership style can suit all situations. This means that some people can perform excellently in certain situations or places but may perform poorly in others. Success depends on a few variables, which include leadership style, attributes of the followers, and the features of the situation (Bass and Avolio, 1994). Hence, it is evident that a certain leadership style will be effective in some circumstances but not in others (Bass and Avolio, 1994). Thus, Contingency theory is an upgrade of the situational viewpoint which concentrates on finding the relevant situational variables that best foretell the best suited or effective leadership style for the very condition or circumstance (Bass and Avolio, 1994; Daft, 2015). Therefore, leaders can scrutinize the very condition and mode their behavior towards that situation to improve effectiveness (Krumm, 2001).

\subsubsection{Influence theories}

One key part of this theory is that of charismatic leadership which refers to that leadership that is not centered on formal authority or position but based on the personality and attributes of the leader (Daft, 2015). It advances that emotional intelligence and the ability to inspire others are necessary for making followers do more than they would normally do. These leaders also influence the followers through enlightenment and compelling vision while shaping the necessary values to actualize the vision (Daft, 2015; Maxwell, 2007).

\subsubsection{Relational theories}

This theory is based on the interaction and influences both the leaders and followers have with each other (Daft, 2015). Daft (2015) further extended that leadership is a relational process that meaningfully engages all participants and enables every individual to play his or her role in the actualization of the vision. This interaction builds a strong relationship and trust which increases motivation between the whole team (Bass, 1998; Daft, 2015). There are two significant relational theories of which are servant leadership and transformational leadership. Servant leaders go beyond self-interest to meet the needs of others and transformational leadership on the other hand comprised of appraising the motivation of the followers while realizing their needs and desires (Chan and Chan, 2005; Daft, 2015). Transformational leaders develop followers into leaders and see to it that each person reaches his or her potential 
(Daft, 2015). Hence, the degree of effectiveness a leader has on his/her followers determines the level of his/her transformational ability; and this, in turn, is shown by the followers' trust and respect toward the leader (Barbuto, 1997).

\subsubsection{Transactional theories}

This theory as the name implies centers on the barter that exists between leaders and their subordinates or mutual benefits based on a form of contract by which the leader presents such things as rewards (whether positive or negative) or esteem the individual, in return for the commitment expressed (Burns, 1978). The transactional theorist understood that as human beings we are in the tendency of harboring individuals that add to our strengths than those who subtract from us (Burns, 1978). For this cause, the transactional theory rests on a series of implicit bargains and exchanges which exist between leaders and followers while clarifying the duties and expectation that is required to actualize the set goals. The efficient rate of transactional leaders is increased when a mutually reinforcing environment is being developed for which the team and organizational goals are in sync (Jarad, 2012).

\section{Research methodology}

A quantitative approach was used in this study which involved the use of a questionnaire. Quantitative research involves a survey to obtain information from a sample of people using self-report from respondents by a sequence of questions posed to them by the researcher (Polit and Hungler, 1995). It is one of the practical approaches to gather information from an extensive sample of respondents using statistics (McCuen et al., 2011). The questionnaire used for this research was divided into Sections A and B. Section A comprised of demographic data such as gender, age, Educational qualification, industrial experience. Section B is comprised of the leadership style actions which can enhance personnel performance. Section B was designed using the 5-point Likert scale rating. Weights were assigned to each response ranging from 1 to 5 from "strongly disagree" to "strongly agree". Convenient sampling was used. 51 construction professionals in the Gauteng Province of South Africa responded to the questionnaire. The professionals were limited to project managers, architects, quantity surveyors, construction managers, civil engineers, and town planners. Data were analyzed using the Statistical Package for Social Sciences (SPSS) version 25.0 software. Mean $(M)$ value was used and the various leadership style actions were ranked accordingly. Measures were taken to ensure that the results of the study are reliable and valid. To start with, clues were taken from previous studies where possible in developing the questionnaire to enhance validity. Hence, the questions were formulated through a detailed literature review and synthesis. Additionally, the research tool (questionnaire) was reviewed by the researcher's supervisor and co-supervisor. Based on the above measures, the content, and face validity of the questionnaire were enhanced (Olson, 2010). The collected data were also valid as they measured what they intended to measure. The reliability and internal consistency of the collected data were appraised using Cronbach's alpha test. The questionnaires measures with $\alpha$ values lower than 0.70 were removed and which enhanced the discriminatory validity of the collected data. Hence, variables with values above 0.70 which indicates good reliability of the internal consistency of the data (Pallant, 2016) were used. The average $\alpha$ value for the leadership style actions was 0.75 .

\section{Findings and discussions}

\subsection{Demographical data of respondents}

This section discusses the background information of respondents. This includes gender, qualifications, professional status, and experience in the industry. The following figures below clearly depicts the full measures of the response of the respondents in terms of demographic data. Fig. 1 reveals that $70.0 \%$ of the respondents were males while $30.0 \%$ were females.

Fig. 2, in terms of educational qualification, depicts that $50.0 \%$ of the respondents had National diploma; $36.0 \%$ had a Bachelor's degree; $10.0 \%$ had a Master's degree, and $4.0 \%$ had a Doctorate degree.

Fig. 3 reveals that quantity surveyors had the highest response rate with $24 \%$ and followed by construction managers with $22.0 \%$. Other respondents include architects $(18.0 \%)$, Civil engineers $(14.0 \%)$, town planners $(14.0 \%)$ and project managers $(8.0 \%)$.

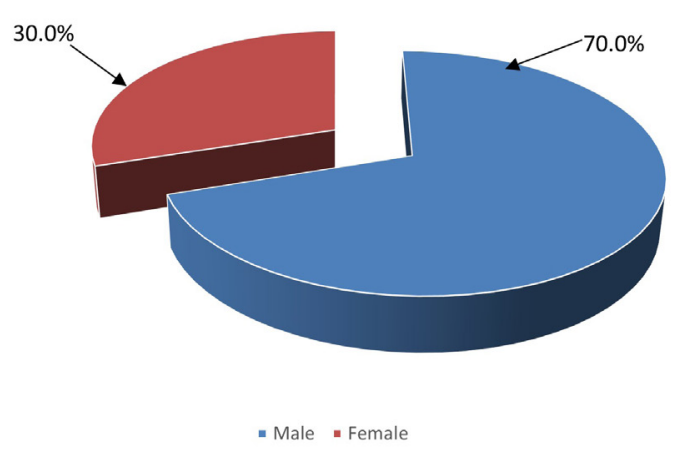

Fig. 1 Respondents' gender 


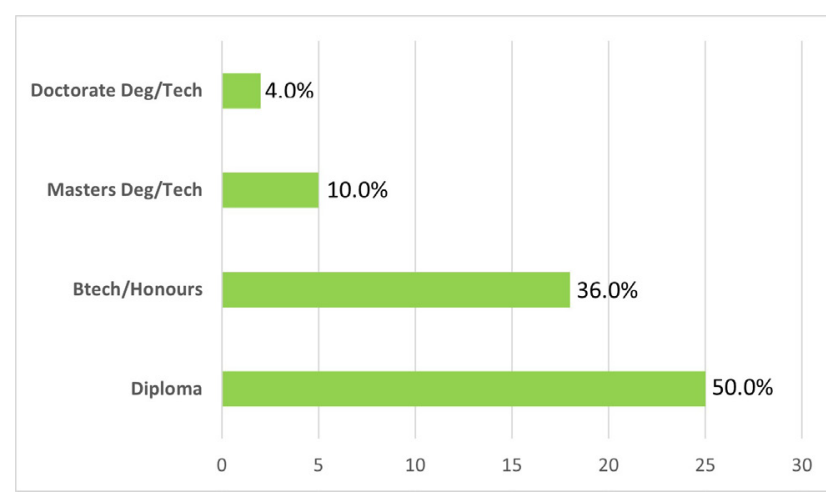

Fig. 2 Respondents' educational qualification

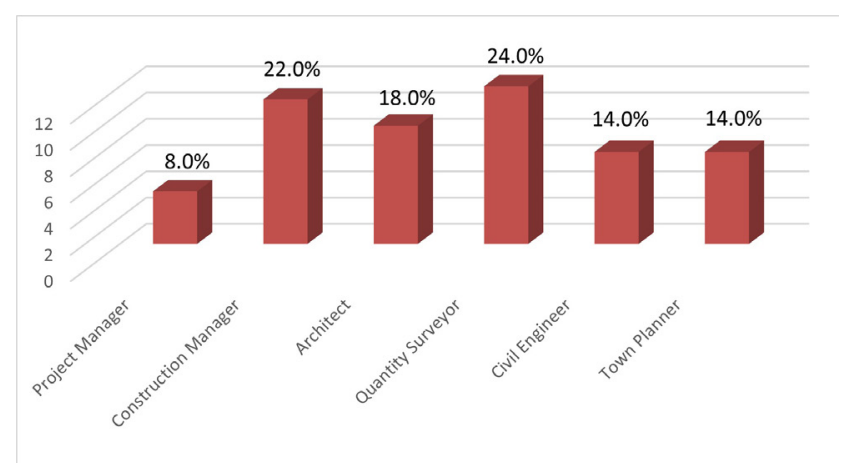

Fig. 3 Respondents' professional status

Fig. 4 depicts the industrial experience of the respondents. It shows that the age group (1-5 years) had $38.0 \%$; followed by $6-10$ years with $36.0 \%$ and $11-15$ years with $14.0 \%$. However, the age groups $16-20$ years, $21-25$ years, 31-35 years had the lowest response rate with $4.0 \%$ each.

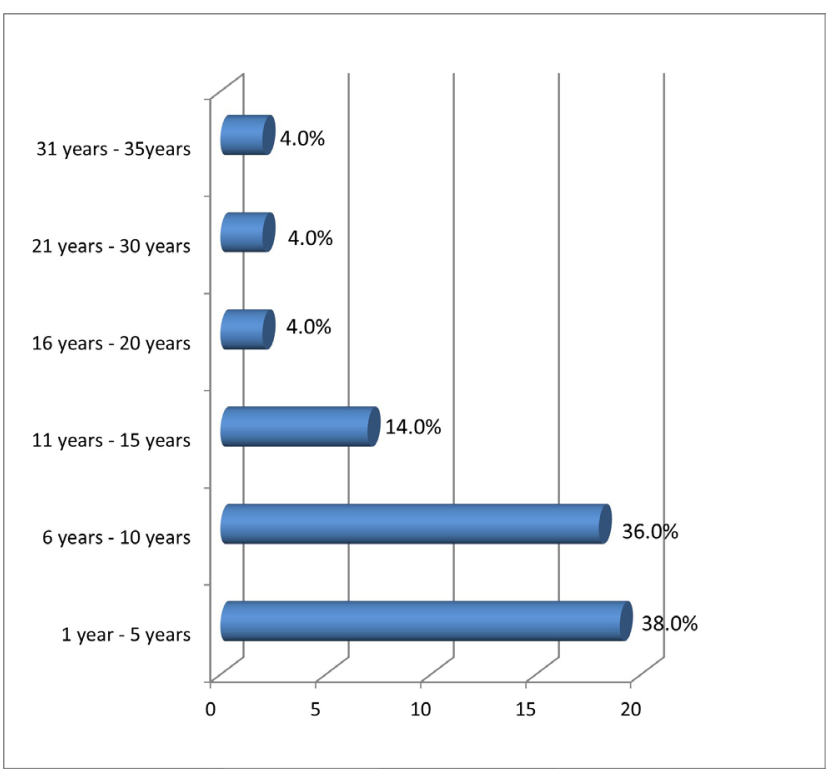

Fig. 4 Respondents' industrial experience

\subsection{Leadership styles action to enhance personnel performance}

The empirical findings centered on the leadership style actions essential for the improvement of personnel performance. Table 1 portrayed the actions according to their leadership style context, while Table 2 portrays the overall rankings of the style actions. The result according to Table 2 revealed that being open to subordinates' ideas contribution within the project environment is of the optimum

Table 1 Leadership style actions to enhance personnel performance

\begin{tabular}{|c|c|c|}
\hline & Mean & Rank \\
\hline \multicolumn{3}{|l|}{ Transactional Leadership Context } \\
\hline $\begin{array}{l}\text { Managing subordinates by the standards agreed } \\
\text { upon. }\end{array}$ & 4.17 & 1 \\
\hline Exercising disciplinary actions for misconduct. & 4.06 & 2 \\
\hline $\begin{array}{l}\text { Focusing on maintaining the stability of the } \\
\text { organization. }\end{array}$ & 4.04 & 3 \\
\hline $\begin{array}{l}\text { Motivating personnel through rewards and } \\
\text { payments. }\end{array}$ & 3.93 & 4 \\
\hline Facilitating events for the workforce. & 3.89 & 5 \\
\hline \multicolumn{3}{|l|}{ Transformational Leadership Context } \\
\hline Representing and upholding good morale. & 4.35 & 1 \\
\hline Assisting others in their self-development. & 4.31 & 2 \\
\hline Inspiring and stimulating followers for action. & 4.29 & 3 \\
\hline Long-range thinking. & 4.23 & 4 \\
\hline Having a primary mission of change. & 3.87 & 5 \\
\hline \multicolumn{3}{|l|}{ Democratic Leadership Context } \\
\hline Being open to subordinates' ideas contribution & 4.42 & 1 \\
\hline Keeping the communication open always. & 4.39 & 2 \\
\hline Encouraging creativity and new ideas. & 4.33 & 3 \\
\hline $\begin{array}{l}\text { Considering feedback from subordinates before } \\
\text { final decision making. }\end{array}$ & 4.17 & 4 \\
\hline $\begin{array}{l}\text { Involving subordinates/employees in project } \\
\text { decision making. }\end{array}$ & 4.14 & 5 \\
\hline \multicolumn{3}{|l|}{ Autocratic Leadership Context } \\
\hline $\begin{array}{l}\text { Close monitoring of projects to ensure the team } \\
\text { meets its goals. }\end{array}$ & 4.10 & 1 \\
\hline Always standing for what I know is right. & 3.79 & 2 \\
\hline Persuading others to do things my way. & 2.72 & 3 \\
\hline $\begin{array}{l}\text { Asking for little or no input from } \\
\text { workers/subordinates. }\end{array}$ & 2.46 & 4 \\
\hline Solely initiating methods and processes. & 2.21 & 5 \\
\hline \multicolumn{3}{|l|}{ Laissez-faire Leadership Context } \\
\hline $\begin{array}{l}\text { Allowing the workforce to work by their } \\
\text { understanding of the work given. }\end{array}$ & 4.16 & 1 \\
\hline $\begin{array}{l}\text { Providing resources to employees/subordinates then } \\
\text { letting them do the work. }\end{array}$ & 4.12 & 2 \\
\hline $\begin{array}{l}\text { Giving subordinates complete freedom } \\
\text { in decision making. }\end{array}$ & 3.62 & 3 \\
\hline
\end{tabular}


Table 2 Leadership style actions to enhance personnel performance [overall ranking]

\begin{tabular}{|c|c|c|}
\hline Leadership style actions & Mean & Rank \\
\hline Being open to subordinates' ideas contribution. & 4.42 & 1 \\
\hline Keeping the communication open always. & 4.39 & 2 \\
\hline Representing and upholding good morale. & 4.35 & 3 \\
\hline Encouraging creativity and new ideas. & 4.33 & 4 \\
\hline Assisting others in their self-development. & 4.31 & 5 \\
\hline Inspiring and stimulating followers for action. & 4.29 & 6 \\
\hline Long-range thinking. & 4.23 & 7 \\
\hline $\begin{array}{l}\text { Considering feedback from subordinates before } \\
\text { final decision making. }\end{array}$ & 4.17 & 8 \\
\hline $\begin{array}{l}\text { Managing subordinates by the standards agreed } \\
\text { upon. }\end{array}$ & 4.17 & 8 \\
\hline $\begin{array}{l}\text { Allowing the workforce to work by their } \\
\text { understanding of the work given. }\end{array}$ & 4.16 & 10 \\
\hline $\begin{array}{l}\text { Involving subordinates/employees in project } \\
\text { decision making. }\end{array}$ & 4.14 & 11 \\
\hline $\begin{array}{l}\text { Providing resources to employees/subordinates then } \\
\text { letting them do the work. }\end{array}$ & 4.12 & 12 \\
\hline $\begin{array}{l}\text { Close monitoring of projects to ensure the team } \\
\text { meets its goals. }\end{array}$ & 4.10 & 13 \\
\hline Exercising disciplinary actions for misconduct. & 4.06 & 14 \\
\hline $\begin{array}{l}\text { Focusing on maintaining the stability of the } \\
\text { organization. }\end{array}$ & 4.04 & 15 \\
\hline $\begin{array}{l}\text { Motivating personnel through rewards and } \\
\text { payments. }\end{array}$ & 3.93 & 16 \\
\hline Facilitating events for the workforce. & 3.89 & 17 \\
\hline Having a primary mission of change. & 3.87 & 18 \\
\hline Always standing for what I know is right. & 3.79 & 19 \\
\hline $\begin{array}{l}\text { Giving subordinates complete freedom } \\
\text { in decision making. }\end{array}$ & 3.62 & 20 \\
\hline Persuading others to do things my way. & 2.72 & 21 \\
\hline $\begin{array}{l}\text { Asking for little or no input from } \\
\text { workers/subordinates. }\end{array}$ & 2.46 & 22 \\
\hline Solely initiating methods and processes. & 2.21 & 23 \\
\hline Cronbach's alpha & \multicolumn{2}{|c|}{0.75} \\
\hline
\end{tabular}

importance having the best ranking and mean $(M)$ value of 4.42. Keeping the communication open always was ranked second with a mean value of 4.39. Representing and upholding good morals was ranked third with a mean value of 4.35. Other results and their rankings were as follows: encouraging creativity and new ideas $(M=4.33$, $R=4)$; assisting others in their self-development ( $M=4.31$; $R=5$ ); inspiring and stimulating subordinates for action ( $M=4.29, R=6)$; long-range thinking $(M S=4.23, R=7)$; collecting feedbacks from subordinates before decision making ( $M=4.17, R=8)$; managing subordinates by the standards agreed upon $(M=4.17, R=8)$; allowing the workforce to work by their "own" understanding of the work given $(M=4.16, R=10)$; involving subordinates/ employees in project decision making $(M=4.14, R=11)$; providing resources to employees/subordinates then letting them do the work $(M=4.12, R=12)$; close monitoring of projects to ensure the team meets its goals $(M=4.10$, $R=13$ ); exercising disciplinary actions for misconducts ( $M=4.06, R=14)$; focusing on maintaining the stability of the organization $(M=4.04, R=15)$ etc. However, it was revealed that "asking for little or no input from subordinates" and "solely initiating methods and processes" were unhealthy for a maximum input of personnel and productivity. Hence, they were the lowest ranked with $(M=2.46$, $R=22)$ and $(M=2.21, R=23)$ respectively.

\section{Conclusions}

The study set out to establish the critical leadership style actions to improve personnel performance in the South African construction industry. Leadership, leadership style, and leadership theory were discussed. Emphasis on leadership and its optimum importance for influencing people and maximizing performance was established. Findings revealed that being open to subordinates' ideas/ contributions is crucial for a leader when working with a group of people. It also revealed that keeping communication open is essential for building rapport. It further revealed that representing and upholding good morals, encouraging creativity and new ideas, assisting others in their self-development, inspiring and stimulating followers for action, long-range thinking, collecting feedback from subordinates before decision-making, inter-alia, are vital for enhancing personnel performance. However, the usage of an autocratic leadership style's actions such as persuading others to do things in the leader's way and not considering possible views from the subordinates is not encouraging. Additionally, the style of leading by solely initiating methods and processes is not favorable to subordinates' performance increase. Leaders should therefore focus on the style actions that produce maximum input from the subordinates. The study adds to the literature on the possible style actions to be adopted for effective leadership in construction project delivery. A leader conversant of the style actions and tailored to the given circumstance will to a great extent win the favor of the subordinates, gain their maximum cooperation, and influence them to get the work done on any given task. Besides, the conscientious display of these styles where necessary among construction personnel when carrying out their project's duties will to a great extent improve the influence the leader has on their subordinates. Positive influence on 
the subordinates towards the attainment of the set goals will result to increase in performance and productivity. Maximum productivity in the construction industry is vital as it employs about $7 \%$ of the total national labor force (Statistics South Africa, 2011). Productivity, therefore, will impact positively on the economic abundance

\section{References}

Adogbo, K. J., Kolo, B. A., Nzekwe, K. C. L. (2017) "Assessment of Organizational Leadership for Knowledge Management Practice in the Nigerian Construction Industry", Journal of Construction Project Management and Innovation, 7(Supplement 1), pp. 1977-1994.

https://doi.org/10.36615/jcpmi.v7iSupplement.148

Barbuto, J. E. (1997) "Taking the Charisma Out of Transformational Leadership", Journal of Social Behavior and Personality, 12(3), pp. 689-697.

Bass, B. M. (1990) "From transactional to transformational leadership: Learning to share the vision", Organizational Dynamics, 18(3), pp. 19-31. https://doi.org/10.1016/0090-2616(90)90061-S

Bass, B. M. (1998) "Transformational Leadership: Industrial, Military, and Educational Impact", Lawrence Erlbaum Associates, Mahwah, NJ, USA.

Bass, B. M., Avolio, B. J. (1994) "Improving Organizational Effectiveness: Through Transformational Leadership", SAGE Publications, Thousand Oaks, CA, USA.

Boerma, M., Coyle, E. A., Dietrich, M. A., Dintzner, M. R., Drayton, S. J., Early, J. L., ... Williams, N. T. (2017) "Point/Counterpoint: Are Outstanding Leaders Born or Made?", American Journal of Pharmaceutical Education, 81(3), Article number: 58. https://doi.org/10.5688/ajpe81358

Bolden, R., Gosling, J., Marturano, A., Dennison, P. (2003) "A Review of Leadership Theory and Competency Frameworks", Centre for Leadership Studies, University of Exeter, Exeter, UK. [online] Available at: http://hdl.handle.net/10036/17494 [Accessed: 14 October 2020]

Burns, J. M. (1978) "Leadership", Harper \& Row, New York, USA.

Chan, A. T. S., Chan, E. H. W. (2005) "Impact of Perceived Leadership Styles on Work Outcomes: Case of Building Professionals", Journal of Construction Engineering and Management, 131(4), pp. 413-422. https://doi.org/10.1061/(ASCE)0733-9364(2005)131:4(413)

Clark, S. N., Clark, D. C. (1994) "Restructuring the Middle-Level School: Implications for School Leaders", State University of New York Press, Albany, NY, USA.

Daft, R. L. (2015) "The Leadership Experience", Cengage Learning, Boston, MA, USA.

DuBrin A, J. (2010) "Principles of Leadership", South-Western Cengage Learning, Mason, OH, USA.

Emere, C. E., Aigbavboa, C. O., Thwala, W. D. (2018) "An investigation of leadership styles of construction professionals in the South African construction industry", In: Creative Construction Conference 2018, Ljubljana, Slovenia, pp. 290-295.

https://doi.org/10.3311/ccc2018-039 of the South African nation as well as add to the gross development product which is about $10 \%$ (Statistics South Africa, 2014). Therefore, adequate leadership is tremendously needed within the construction sector for efficiency and productivity.

Furnham, A. (2005) "Leadership", In: The Psychology of Behavior at Work: The individual in the Organization, Psychology Press, New York, USA, pp. 566-607.

Giritli, H., Oraz, G. T. (2004) "Leadership styles: some evidence from the Turkish construction industry", Construction Management and Economics, 22(3), pp. 253-262. https://doi.org/10.1080/01446190310001630993

Groetsch, D. L., Davis, S. B. (2006) "Quality Management: Introduction to Total Quality Management for Production, Processing, and Services", Pearson Prentice Hall, Hoboken, New Jersey, USA.

Havenga, R. (2002) "The new leadership challenge: Teaming principles with practices in times of change", Management Today, 9(3), pp. 225-247.

Jarad, N. G. I. (2012) "The Construction Manager Leading Characteristics for the Success of Construction Projects in the Gaza Strip", Master Thesis, The Islamic University of Gaza.

Kotter, J. P. (1988) "The Leadership Factor", Free Press, New York, NY, USA.

Kouzes, J. M., Posner, B. Z. (1996) "The Leadership Challenge: How to Keep Getting Extraordinary Things Done in Organisation", Jossey-Bass Publishers, San Francisco, CA, USA.

Krumm, D. J. (2001) "Leadership", In: Psychology at work: An introduction to industrial/organizational psychology, Worth Publishers, New York, NY, USA, pp. 235-278.

Liphadzi, M. (2015) "Leadership style practices of construction and project managers in the South African construction industry", Master Dissertation, University of Johannesburg.

Maxwell, J. C. (2007) "The 21 Indispensable Qualities of a Leader: Becoming the Person Others Will Want to Follow", Thomas Nelson, Nashville, TN, USA.

McCuen, R. H., Ezzell, E. Z., Wong, M. K. (2011) "Fundamentals of Civil Engineering: An Introduction to the ASCE Body of Knowledge", CRC Press, Boca Raton, FL, USA.

https://doi.org/10.1201/b10733

Müller, R., Turner, R. (2007) "The Influence of Project Managers on Project Success Criteria and Project Success by Type of Project", European Management Journal, 25(4), pp. 298-309. https://doi.org/10.1016/j.emj.2007.06.003

Munroe, M. (2005) "Spirit of Leadership", Whitaker House, New Kensington, PA, USA.

Olson, K. (2010) "An Examination of Questionnaire Evaluation by Expert Reviewers", Field Methods, 22(4), pp. 295-318. https://doi.org/10.1177/1525822X10379795

Okoroji, L. I., Anyanwu, O. J., Ukpere, W. I. (2014) "Impact of Leadership Styles on Teaching and Learning Process in Imo State", Mediterranean Journal of Social Sciences, 5(4), pp. 180-193. https://doi.org/10.5901/mjss.2014.v5n4p180 
Pallant, J. (2016) "SPSS Survival Manual: A Step by Step Guide to Data Analysis Using IBM SPSS", McGraw-Hill Education, Maidenhead, UK.

Polit, D. F., Hungler, B. P. (1995) "Nursing research: Principles and methods", Lippincott Williams and Wilkins, Philadelphia, PA, USA.

Price, J. J. (2009) "The Conception and Operationalization of leadership in construction companies", Master Thesis, University of South Africa.

Statistics South Africa (2011) "Census in brief", [pdf] Statistics South Africa, Pretoria, South Africa, Available at: http://www.statssa. gov.za/census/census_2011/census_products/Census_2011_ Census_in_brief.pdf [Accessed: 05 April 2020]

Statistics South Africa (2014) "Gross domestic product: Annual estimates 2004-2013, Regional estimates 2004-2013, Third quarter 2014", [pdf] Statistics South Africa, Pretoria, South Africa, Statistical release PO441. Available at: http://www.statssa.gov.za/publications/ P0441/P04413rdQuarter2014.pdf [Accessed: 06 April 2020]
Stoner, J. A. F., Freeman, R. E. (1989) "Management", Prentice-Hall, Englewood Cliffs, NJ, USA.

Tabassi, A. A., Bakar, A. H. A. (2010) "Towards assessing the leadership style and quality of transformational leadership: The case of construction firms of Iran", Journal of Technology Management in China, 5(3), pp. 245-258. https://doi.org/10.1108/17468771011086256

Wren, J. T. (1995) "The Leader's Companion; Insights on Leadership Through the Ages", Free Press, New York, NY, USA. 